\title{
Nationality and Citizenship in the Irish Home Rule Debates of 1886
}

Nationalité et citoyenneté dans les débats sur le Home Rule irlandais (1886)

Pauline Collombier-Lakeman

\section{(2) OpenEdition}

\section{Journals}

Electronic version

URL: http://journals.openedition.org/rfcb/760

DOI: $10.4000 /$ rfcb.760

ISSN: 2429-4373

Publisher

CRECIB - Centre de recherche et d'études en civilisation britannique

Electronic reference

Pauline Collombier-Lakeman, "Nationality and Citizenship in the Irish Home Rule Debates of 1886 », Revue Française de Civilisation Britannique [Online], XXI-1 | 2016, Online since 20 July 2016, connection on 01 May 2019. URL : http://journals.openedition.org/rfcb/760 ; DOI : 10.4000/rfcb.760

This text was automatically generated on 1 May 2019.

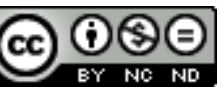

Revue française de civilisation britannique est mis à disposition selon les termes de la licence Creative Commons Attribution - Pas d'Utilisation Commerciale - Pas de Modification 4.0 International. 


\title{
Nationality and Citizenship in the Irish Home Rule Debates of 1886
}

Nationalité et citoyenneté dans les débats sur le Home Rule irlandais (1886)

\author{
Pauline Collombier-Lakeman
}

\section{Introduction}

1 According to French sociologist Dominique Schnapper, there is a connection between citizenship and nationality, which is notably illustrated by the struggle of colonised peoples against their colonisers and their claim that political independence goes hand in hand with the assertion of citizenship:

Dans tous les mouvements d'indépendance en Europe et en Amérique au XVIIIe et XIXe siècles, en Afrique et en Asie au XXe siècle, la revendication à l'indépendance nationale ne se séparait pas de l'affirmation de la citoyenneté. C'est au nom des valeurs de la citoyenneté que les peuples colonisés se sont révoltés contre la domination des colonisateurs européens. ${ }^{1}$

2 The Act of Union of 1800 turned Ireland into a province of the United Kingdom, establishing a political, economic and religious union between Ireland and Great Britain. This theoretically placed Ireland on an equal footing with the other British nations and historians like Stephen Howe do sustain the idea that, following the repeal of the Penal Laws at the end of the 18th century and the Emancipation of Catholics in 1829, the Irish enjoyed political rights similar to those of their fellow British citizens since they gradually benefited from a wider and wider franchise, as in the rest of the United Kingdom. ${ }^{2}$ However, such an interpretation of the relationship between Ireland and its neighbour has been contested by a number of academics, who have underlined that, in practice, Ireland was treated by Britain more as a colony than as a province. Peter Gray for instance has underlined that the Irish executive remained headed by a Viceroy or Lord-Lieutenant who was commonly regarded as a sort of colonial governor. ${ }^{3}$ Before him, Theodore K. Hoppen had also emphasised inequalities between Ireland and England in his work regarding the successive Irish Reform Acts between 1832 and 1885: 
(...) [I]n 1867 the franchises of the two countries had once again moved apart after the comparative alignment of the years since the Irish Act of 1850. The dramatic growth of the English borough electorate and the smaller but still significant county increase produced by the Second Reform Act had not equivalent in Ireland. There an extremely mouse-like Act in 1868 left the important county franchise quite alone and merely reduced the valuation required for the borough vote from eight pounds to over four pounds. Boundary changes aside this probably increased the Irish borough electorate by less than 10,000. Once again, very much larger percentage of adult males had the vote in England and Scotland than in Ireland. ${ }^{4}$

Gray and Hoppen defended what could be regarded as a reassertion of Ireland's colonial status under the Union with Britain, which echoes some of the arguments used by Irish nationalists, as Irish nationalism developed in the 19th century to question the link existing between Ireland and Britain. Even Irish moderate nationalists, who formed the dominant movement until 1918 in Ireland, repeatedly denounced what they considered to be an unlawful and unbearable domination of Ireland by Britain while claiming to avoid total political separation from the United Kingdom and the British Crown.

The first debates on an Irish Home Rule Bill in the British Parliament (1886) are a good illustration of this tradition in the Irish nationalist discourse and shed light on how both the Irish and British political elites variously associated nationality and citizenship. While the Irish nationalist MPs and their Liberal allies headed by Prime Minister W. E. Gladstone defended the idea that the Irish were civilised enough to obtain their own local parliament and act as responsible citizens in a self-governing entity, Conservatives and Unionists - British Liberal Unionists as well as Irish Unionists - would emphasise that the Irish were either too barbaric/primitive or bigoted to be trusted with any form of legislative autonomy. Whereas Irish nationalist MPs strove to promote the idea of a united nation of Irish citizens transcending religious differences, their anti-Home Rule counterparts agitated the fear that Home Rule meant Rome Rule and that a selfgoverning Ireland would quickly lead to tyranny and even possibly civil war.

\section{The British discourse split along Home Rule lines}

\section{The British political context}

5 In Britain the issue of Home Rule for Ireland provoked deep modifications in the British political landscape. A shift in allegiances and a redefinition of political lines took place in 1885-6 following a succession of very important political events.

6 First the Franchise Act of 1884 and the Redistribution Act of 1885 both contributed to greatly increase the size of the electorate in the United Kingdom, including Ireland. This was particularly important as general elections were planned to take place in December $1885 . .^{5}$

7 It was already clear prior to these elections that both British parties had diverging views regarding Home Rule for Ireland. These views were first stated unofficially; in early July 1885, Lord Salisbury told the Irish Lord Lieutenant Lord Carnavon of his "strong objection to Home Rule"; 6 at the same time Gladstone's opinion on the subject had been evolving and from August $1885^{7}$ the Liberal leader exchanged letters with the Irish nationalist leader Charles Stewart Parnell. ${ }^{8}$

At the end of 1885, the election of 86 Irish nationalist MPs against 335 Liberal MPs and 249 Conservative MPs meant that, for the first time, the Irish held the balance 
of power in the House of Commons. The two British political parties were thus forced to take clear public positions regarding their commitment or not to grant Home Rule to the Irish. When Prime Minister Lord Salisbury announced the implementation of a new scheme of coercion in Ireland on 21 January $1886,{ }^{9}$ the Liberals struck an alliance with the Irish nationalists to take down the Conservative government (26 January)to bring the Conservative government down. ${ }^{10}$ The Liberals then formed a new government (1 February) but this meant that Gladstone had to promise in return to introduce a Home Rule Bill for Ireland (4 February). ${ }^{11}$ one hand, the pro Home-Rule Liberals headed by Gladstone and, on the other hand, the Liberal Unionists allied to the Conservatives, who were all staunchly opposed to the political autonomy of Ireland. The House of Commons was therefore "[polarised] along ideological and regional lines." ${ }^{15}$

\section{The Liberal point of view on the Irish as citizens}

This political split along Home Rule lines is reflected in the way speeches from supporters in each group contradicted one another during the debates and in the very different approach orators had to the link between nationality and citizenship. One of the recurrent arguments used by Gladstone focuses on the failure of coercion in Ireland over the years. According to Gladstone, intimidation had only led to a decrease in "respect for law, and the respect for contract, and that among a people who, I believe, [were] as capable of attaining to the very highest moral and social standards as any people on the face of the earth." 16 In these circumstances, self-government is the key solution to "restore social order", peace and loyalty and to avoid crime and violence:

[S]omething must be done, something is imperatively demanded from us to restore to Ireland the first conditions of civil life-the free course of law, the liberty of every individual in the exercise of every legal right, the confidence of the people in the law, and their sympathy with the law, apart from which no country can be called, in the full sense of the word, a civilized country, nor can there be given to that country the blessings which it is the object of civilized society to attain. ${ }^{17}$

11 As the first quote suggests, such a view was based on the conviction that the Irish had the full capacity to govern themselves and be citizens: for Gladstone, they could become members of a self-governing and responsible political community in which they would all participate and have similar duties and rights. Such a belief was to transpire again in Gladstone's speeches, when he disparaged prejudiced views presenting the Irish as lacking the qualities that would make them eligible to citizenship - in other words, prejudiced views presenting the Irish somehow as second-class citizens:

[T] he view which rests upon the basis of despair and of absolute condemnation of Ireland and Irishmen as exceptions to the beneficent provisions which enable men in general, and Europeans in particular, and Americans, to be capable of performing civil duties, and which considers an Irishman either as a lusus naturœ or one for whom justice, common sense, moderation, and national prosperity have no 
meaning, and who can only understand and appreciate perpetual strife and dissension (...) is founded on a monstrous misconception..$^{18}$ project. Within the government, the Chief Secretary for Ireland John Morley and the Attorney-General Sir Charles Russell both defended Home Rule for Ireland on the grounds that the Irish people had enough knowledge of civic rights and duties to establish a sustainable and reasonable system of self-government. Morley expressed faith in the capacity of the Irish but could not help sounding slightly patronising and paternalistic:

Therefore, I am not, Sir, going to admit that in constituting an Irish legislature you are going to have a collection of worthless "ne'er-do-wells." It may be that the Irish Assembly may not have the superfine manners which distinguish this Assembly, and that it may be a little ruder in its ways. I believe that it will be as capable of performing the duties of a Legislature with a spirit of justice and of competency for its purposes as any body of men that can be found (...). ${ }^{19}$

Russell was less ambiguously positive, lavishing praise on Irish skills and minimising or rather finding excuses for Irish discontent:

[L]et me assure the House that I will not condescend to argue this question as though the Irish nation were to be treated as a nation of fools or of criminals. I claim, in forecasting their probable course of action, the right of the Irish nation to be regarded as a people having a fair share of natural acuteness, and of such intelligence as will enable them to deal with their own interests and concerns in a practical and business-like manner.

I ask the House to approach this question in a spirit of some trust in Irishmen. I ask it not to condemn the Irish people as a criminal nation, because of the faults of many individuals among them, faults which we deplore, but faults and crimes committed in times of great national pressure, almost of national revolution. We believe - I ask the House to believe - that there are in the Irish people solid qualities, solid virtues, which, given fair play, will assert themselves in the world. ${ }^{20}$

Both Morley and Russell are known to have been staunch supporters of the Irish cause. To explain the difference between the two quotes, we can add that Russell was an Irishman from county Down, and prior to his political career in England, had been a correspondent of the Dublin nationalist newspaper The Nation. Considering Morley's or Russell's backgrounds and their common position on Home Rule, it is therefore not surprising to find in their speeches expressions of faith in the capacity of the Irish to act as responsible citizens. At the same time, these quotes can be seen as responses to or warnings against possible prejudices and therefore they serve to highlight the persistence of prejudiced views against the Irish in the British Parliament.

\section{The Conservative and Liberal-Unionist point of view on the Irish as citizens}

Conservatives and Liberal Unionists were opposed to Home Rule for a number of reasons. Not only did they fear for the integrity and supremacy of the British empire but they also had two further concerns: first, Home Rule meant Rome Rule, which highlighted a threat for the Protestant minority and a risk of civil war in Ireland; secondly, some of them also believed that the Irish were not politically astute enough to be able to control their own fate. Such was the case for a prominent figure like Sir Michael Hicks-Beach, leader of the Conservatives in the House of Commons: 
Well, Sir, in my humble opinion, the right hon. Gentleman has taken a most extraordinary means, on his own showing, of restoring social order to Ireland. He has borrowed the policy which was proposed by the Chief Secretary for Ireland before he was a Member of the Government. That right hon. Gentleman then recommended the Government of the day to capture the Leaders of the Irish Revolutionary Party and to give them power in order to make them responsible. This policy is nothing less than giving up the enforcement of the law in despair. ${ }^{21}$

The Marquess of Hartington, soon to be Leader of the Liberal Unionists, even went further since he questioned the political legitimacy acquired by the Irish parliamentary party after its 1885 victory in Ireland through associating it with crime and "lawlessness":

On [respect for law and human life] I think O'Connell was consistent; and I believe he was unimpeachable. Mr. Parnell is somewhat copious in his references to America. He seems to set up America as the true and only friend of Ireland; but in all his references to America he has never found time to utter one word of disapproval or misgiving about what is known as the assassination literature of that country. (...) I see no reason, simply because the Party professing those principles has acquired greater strength and possibly a greater claim to represent a larger number of the people of Ireland - I see no reason why we are to retire from that which has been called by my right hon. Friend a conflict between law on the one side and sheer lawlessness on the other, and why are we to sacrifice, without any further struggle, the principles upon which, in the opinion of my right hon. Friend at that time, the structure and basis of society reposed. ${ }^{22}$

Both Hicks-Beach and Hartington could be regarded as experts on Ireland since both had been Irish Chief Secretaries (Hartington between 1871 \& 1874 and Hicks Beach between 1874 \& 1878). However, the deep negativity of Hartington's speech may also be explained by personal bitterness and prejudice for Hartington's younger brother Lord Frederick Cavendish had been brutally murdered by Irish extremists in Phoenix Park on 6 May 1882, a few weeks only after coming to Ireland as the new Irish Chief Secretary. In 1885, it was clear that Hartington had become uncomfortable with Gladstone's policy of conciliation towards Ireland and as a result, he had even declined to serve in the Liberal administration formed in February 1886.

The views of Hicks-Beach and Hartington were shared by less prominent MPs such as the Conservatives John George Gibson, M. P. for Liverpool-Walton, Ellis Ashmead Bartlett, M. P. for Ecclesall, Lord George Francis Hamilton, M. P. for Middlesex, Ernest William Beckett, M. P. for York, or again the Liberal Unionist George Goshen, M. P. for Edinburgh. Some of Ashmead-Bartlett's arguments for instance echoed those of Hartington as he linked once more the Irish Parliamentary Party to crime - notably to violence that emerged during the Land War (1879-1881); as a result doubt was again strongly cast upon the legitimacy of the party to act as a democratic and peaceful actor in the future Home Rule Parliament in Ireland:

The entire civil administration of Ireland is to be in the hands of the new Irish Parliament; that is, every town and district in Ireland will be administered by the National League-by the lawbreakers, village tyrants, "Boycotters", and blackmailers who constitute the agents and the power of the League. It is too probable that the darker and more dangerous Irish conspirators across the Atlantic will really control the new Parliament and its policy. Ireland will, therefore, be in a very brief space, organized and guided by those unfriendly, perhaps by those bitterly hostile, to Great Britain and to everything British - hostile to our race, creed, laws, and form of government. ${ }^{23}$

In other speeches, the Irish people as a whole were criticised. L. G. Hamilton for example used the argument of illiteracy to minimise the impact of the Nationalist victory in 
December 1885 and to deny the importance of the popular support the Irish Parliamentary Party could rely on:

Are these men who have returned the Friends of the hon. Member for the City of Cork ignorant and illiterate, or are they capable citizens? (...) Having looked through these figures I may say that about one-third of all the Nationalist votes polled in Ireland were given by persons who can neither read nor write. Therefore, not merely are the Loyalists of Ireland one-third of the population; but I say unhesitatingly that if you take any of the criteria by which you judge who are capable citizens-intelligence, thrift, freedom from crime, absence of pauperism, capacity for work, success in industrial occupation, or improved methods of agriculture - if you take any one of these tests you will find more capable citizens among the Unionists than among the Nationalists. ${ }^{24}$

Discourse reflected the values and beliefs of the Victorian age and also highlighted that moral advances needed to be made for the Irish to become citizens and to be regarded as potential democratic subjects:

[W]ithout looking upon the Irish people as lost to the common virtues of civilized communities, we may think that they are not such an angelic people as to be likely to be suddenly transformed at one stroke of the pen, and all at once endowed with the faculty of governing themselves. No people with, such antecedents as the Irish could be suddenly trusted with the unexampled powers which he proposes to confer on them. ${ }^{25}$

21 As was often the case with these stereotyped views of the Irish, speeches could be prone to violence, as is epitomised by the example of E. W. Beckett, whose discourse became pervaded at times with interrogative and negative forms and vehement language (" tyranny", “crush out”, "barbaric", “horror", "vicious", “Thugs"):

Another cry is that Ireland must be governed according to Irish ideas. What are Irish ideas of government? Have they ever been defined? Do they exist at all except as a phrase? Are we sure that government, according to Irish ideas, is not misgovernment according to English ideas? (...) Sir, Ireland is now governed according to Irish ideas; and what do we see? Liberty of speech, liberty of action, liberty of conscience, sore beset and hindered, and almost ceasing to struggle for existence. We see the whole nation, all but the brave North, in the grasp of an iron tyranny that threatens to crush out all healthy life. We have seen that tyranny imposed upon the people by a series of barbaric crimes and brutal outrages that have excited horror and indignation throughout the civilized world. (...) I think I have said enough to show that the Nationalists are in no true sense Representatives of Ireland, or if they are they represent what is worst in Ireland and ought to be suppressed, not what is best and ought to be encouraged. On behalf of the idle and vicious they come here, not on behalf of the industrious and respectable. They have usurped the name of the Irish nation; but the true Ireland has not spoken, and cannot speak, while she is in the hands of Thugs. ${ }^{26}$

This type of portrait of the Irish was not new. It borrowed from a long tradition in the English and British discourse on the Irish, which Andrew Hadfield traces back to the 12th century, and which survived well into the 19th century. ${ }^{27}$ Hostile views regarding the political capacities of the Irish persisted in Britain and British discourse well after Daniel O'Connell's campaign for the Repeal of the Union in the 1830s and 1840s, as Lionel Perry Curtis Jr. underlines:

[M]any cartoons in Punch harped on such negative aspects (...) as gullibility, childishness, Anglophobia, fondness for drink, ignorance, indolence, clericalism, and fanaticism. Because these traits were represented as uniquely Irish and therefore wholly un-English, they were bound to reinforce the widespread conviction in Britain that the Gaelic Irish, in particular, those who supported 
Fenianism or the Land League, were unfit for self-government. Needless to say, such negative stereotyping had the effect of reducing Irishmen who advocated some form of autonomy to a 'race' of degenerate, grunting, shillelagh-wielding, and priest-ridden Yahoos. ${ }^{28}$

All these quotes from Conservative and Liberal Unionist frontbenchers and backbenchers raise the question of what citizenship meant in the 19th century and bring to the fore the paradoxes present in the Conservative and Liberal Unionist discourse at the time. It seems that double standards were employed: while Conservatives and Liberal Unionists were attached to the Union and accepted the presence of Irish representatives in the House of Commons as decided by the Union Act of 1800, they rejected the idea of Irish political autonomy and, as a consequence, questioned the possibility for Irish representatives to sit in a Parliament of their own.

By strongly linking citizenship and morality, Conservative and Liberal Unionist MPs also foreshadowed the turn Conservative policies towards Ireland were to take in the late 1880s. Once the Tories were back in government with Lord Salisbury as Prime Minister and Arthur Balfour as Irish Chief Secretary, they opted once more for coercion with the vote of a Criminal Law and Procedure Act or Crimes Act (50 \& 51 Vict. c. 20), which allowed the Lord Lieutenant to prohibit or suppress by proclamation "dangerous associations" and resulted in the proclamation of the Irish National League as a "dangerous association". ${ }^{29}$ Unionists of all shades then went further in their campaign to bring down Irish nationalism: a series of articles entitled "Parnellism and Crime" was published in The Times,${ }^{30}$ followed by letters supposedly written and signed by Charles Stewart Parnell, expressing his support for illegal activities and the political use of violence and condoning the 1882 Phoenix Park assassinations ${ }^{31}$. As a result, a Special Commission was put into place to examine the authenticity of these letters and, more generally, to investigate the possible connections between the National League and the more radical and revolutionary nationalist organisations. ${ }^{32}$ Even though the Times letters were eventually revealed to be forgeries, ${ }^{33}$ the fact remains that from 1887 onwards, the Conservatives followed a clear political strategy targeting Parnell and his party and aiming at discrediting both by associating them with crime and extreme nationalism. As Margaret Callaghan emphasises:

The Special Commission was constructed to render the Irish parliamentary party constitutionally impotent, since it established them as criminals. (...) From 1876 to 1886 Irish nationalism had evolved from a crude agrarian base to a sophisticated political strategy. The achievement of Arthur Balfour's Irish chief-secretaryship was to negate that development and remould the nature of the Irish challenge to a parody of the confused agrarian conspiracy of 1879-1881. ${ }^{34}$

It is obvious that such a strategy aiming at dismissing the Irish Parliamentary Party's legitimacy by linking it to violence was already well-employed during the Home Rule debates of 1886 .

\section{The Irish discourse split along sectarian lines?}

\section{The political context in Ireland}

In Ireland, the Home Rule debates modified the political landscape. Prior to the electoral reforms of 1884 \& 1885, Irish moderate nationalism had been revived under the leadership of Charles Stewart Parnell with the creation of the Irish National League (17 
October 1882$)^{35}$ and the introduction of strict rules for the future Irish MPs - in particular a solemn pledge "to vote, sit, and act with the Irish Parliamentary Party" (August 1884). ${ }^{36}$

As stated earlier, the Irish Parliamentary Party won 86 seats at the 1885 general elections, including 1 in Great Britain, which resulted in a hung Parliament. For the first time the nationalist party was the strongest party in Ireland, had won elections in Ulster and had enough seats compared to the Liberals and Conservatives to become the third political force in the House of Commons. ${ }^{37}$

28 At the same time, the electoral victory of the Irish nationalists as well as the conversion of Gladstone and a majority of British Liberals to Irish Home Rule led to a notable development of Irish unionism, especially in Ulster: a small "Ulster Party" or "Ulster Unionist Party" was formed in the House of Commons ${ }^{38}$ and was backed by diverse associations throughout Ireland - the Irish Loyal and Patriotic union created in May 1885 in Dublin; the Loyal Irish Union established in Belfast in August $1885^{39}$ and, in 1886, the Ulster Loyalist anti-Repeal Committee (quickly renamed Ulster Loyalist anti-Repeal Union $)^{40}$ as well as an Ulster Liberal Unionist Committee put into place in June. ${ }^{41}$

Reversing roles and creating the myth of an Irish civic nation: the Irish as potential model citizens

In these new circumstances, how did the Irish nationalist MPs led by Parnell respond to both their British and Irish critics? Was the claim of the Irish to self-government based on the assumption that the Irish could be responsible citizens if they were given their own institutions?

31 A couple of strategies can be identified in the Irish nationalist speeches delivered in the Commons between April and June 1886. The first strategy is based on an opposition of words and images and a reversal of roles between Britain and Ireland. While Conservatives and Unionists would emphasise that the Irish were too barbaric or too bigoted to be trusted with political autonomy, the Irish nationalist MPs, just like their Liberal allies, defended the idea that the Irish were civilised and politically astute enough to obtain their own local parliament and act responsibly in a self-governing entity. This strategy was adopted by prominent figures in the Irish Parliamentary Party such as T. D. Sullivan, Mayor of Dublin and MP for Dublin College Green:
Lord Salisbury said that the Irish Representatives would not only say anything, but that they would swear anything. He charged them, not only with being liars and perjurers, but with sympathizing with all those criminal and evil doings which had occurred in their unfortunate country. But if they were such a class of men as that, why were they to be retained at Westminster for the protection of Imperial interests? They were charged with being the implacable enemies of the Empire, the irreconcilable enemies of England. If that were so, here it was, with their hands upon the springs of Imperial power, that they could, if such was their desire, on many and important and critical questions, do injury to the interests of this country and of the Empire..$^{42}$

In Ulster, where the Nationalists had managed to win 17 seats against 16 for the Conservatives, it was even more crucial to emphasise the political capability of the Irish people, especially of the Irish Catholics. That is why Timothy Healy, MP for South Londonderry, also highlighted the political experience acquired by the Irish by referring to some of the most prestigious Irish-born politicians such as Edmund Burke or the Duke of Wellington: 
I think that, taking them as a whole, we may claim for this Party - a Party coming here at a great distance from their farms, their workshops, counting-houses, and professions - that it represents as much intelligence, and, perhaps, although I should not say so, as much righteousness and conscientiousness as any other Party in this House. (...) I say, do they not show as much worth as the claimants of a monopoly of the intelligence, culture, and wealth of Ireland? We cannot admit North-East Ulster's modest claim to all the talents and all the virtues. When England wanted statesmen, she did not care from what part of Ireland she got them; she did not ask whether Burke was a Cork man or an Ulster man, or whether or not Lord Wolseley was a Northerner; and whenever the question was asked, the Duke of Wellington's capacity was allowed, although he was born near Dublin. Having had these products from Ireland in the past, having had the privilege of giving you Irish Premiers, and the leadership of Irish Generals, I venture to think that the people of Ireland are just as capable of carrying out a moderate and sober system of self-government as any people on the globe. ${ }^{43}$

Another strategy that can be identified in the Irish nationalist discourse in Parliament relies on the construction of new myths and images for the nation. A striking point of Parnell's speech on 7 June 1886 is a reference he includes to the 18th century Irish Parliament also known as "Grattan's Parliament." ${ }^{44}$ There is no doubt that Parnell did not seriously consider re-establishing Grattan's Parliament. However, referring to it was not fortuitous: as historian Olivier McDonagh has pointed out, Grattan's Parliament was used as an "incantation". In other words, it came to be mentioned by Parnell in the course of the debates because of its symbolic value as a founding event and important precedent in Irish political history. Referring to Grattan's Parliament was a way for Parnell and his colleagues, through creating a sense of continuity in Irish history, to establish ties of kingship with a Protestant Parliament and to assert Ireland's capacity to abide by parliamentary rules and become a peaceful self-governing nation. Thus Parnell could be seen here as turning Grattan's Parliament into what historian Moses Finley has named an "ancestral constitution", which gave legitimacy to the Irish nationalist claim that the Irish people had acquired plenty of perfectly valid political experience and should therefore be allowed to govern themselves.

Re-imagining Ireland was all the more crucial as the Irish nationalist MPs were faced with the necessity of addressing prophecies of civil war between Irish Catholics and Irish Protestants. In order to counteract suggestions by the Unionists of all sides that Catholics would persecute Protestants in a self-governed Ireland, Irish MPs repeatedly emphasised the possibility to reconcile communities into one nation with common memories, as in the case of John Dillon.

We pledge ourselves to use our utmost influence and whatever popularity we possess to make the Bill acceptable to the Irish people, and to make it we pledge ourselves that whatever power we have with the Irish people shall be used to get this bill accepted, not alone in its letter, but in its spirit, as a means to unite our people and to govern the country with a view to its future prosperity. ${ }^{45}$

Once more, history was instrumental in asserting the commitment of the Irish nationalists and Irish Catholics to the ideal of a united nation, as is shown by another Irish Parliamentary Party leader, William O'Brien:

We are not afraid of their having the most ample power in our Irish parliament. We are bound by dear and sacred ties to our Protestant fellow -countrymen. In spite of what is said in this house, our country is one country. The race which gave us Grattan and Emmett, and Davitt, and Butt, and Parnell, is not a foreign race. ${ }^{46}$ 


\section{Conclusion}

With such words, the Irish parliamentary nationalists were offering a political alternative to strife and civil war. They were also forging what could be regarded as another myth 喵 a "myth of union" (mythe de l'unité) to quote Raoul Girardet, or even a "myth of the civic nation" to use the phrase coined by Bernard Yack. ${ }^{47}$ To stress the idea of possible harmony and peace in Ireland, Irish nationalist MPs and their leadership undertook to rebuild the nation on new foundations and thus stressed converging interests and cohesion while rejecting division. In other words Irish nationalist MPs defined an Irish nationality, which relied heavily on the notion of a common and shared citizenship transcending particular and individual differences, especially religious differences.

In La Communauté des citoyens, Sur l'idée moderne de nation (1994), Dominique Schnapper also evokes the nation as a civic community:

La spécificité de la nation moderne consiste à intégrer toutes les populations en une communauté de citoyens (...). La nation se définit par son ambition de transcender par la citoyenneté des appartenances particulières, biologiques, historiques, économiques, sociales, religieuses ou culturelles. ${ }^{48}$

At the same time, like Girardet and Yack, Schnapper recognises the limits of purely abstract or imaginary representations of the civic nation and admits the possibility that the civic nation may turn out to be more a myth than a concrete possibility:

Affirmer le principe de la citoyenneté ne suffirait pas en effet par soi seul à constituer une communauté de citoyens. Souveraineté et citoyenneté sont des fictions. On ne mobilise pas les individus sur des idées aussi abstraites. On ne peut les intégrer effectivement qu'au nom d'un certain nombre de réalités concrètes, valeurs et intérêts (...). On ne peut les intégrer que par l'action continue d'institutions communes, au sens large que Durkheim donne à ce terme, formes constituées de pratiques par lesquelles les générations se transmettent les manières d'être et de vivre ensemble caractéristiques d'une collectivité historique particulière. ${ }^{49}$

In the case of Ireland it appears that the Irish parliamentary nationalists dreamed the Irish nation as a civic nation transcending all differences but failed to acknowledge harsher realities such as the rise of Irish unionism and unionist discontent. This resulted in further political defeats about thirty years after 1886: despite being voted by the British Parliament and receiving royal assent in 1914, the third Home Rule Bill for Ireland was suspended; at the general elections of 1918 the Irish Parliamentary Party also lost considerable ground in Ireland to the more extreme and radical groups of Irish nationalists-notably Sinn Féin.

Pauline Collombier-Lakeman was awarded her PhD on the topic of Le discours des leaders du nationalisme constitutionnel irlandais sur l'autonomie de l'Irlande : utopies politiques et mythes identitaires from the Université Paris 3-Sorbonne Nouvelle in 2007. Her current research work is focused on Irish parliamentary nationalism and on the relationship between Ireland and the British Empire. Recent publications include a contribution to G. Doherty (ed.), The Home Rule Crisis 1912-14, Cork: Mercier Press, 2014 \& a book cowritten with Prof. Peter Gray: La Grande Famine en Irlande, 1845-1851, Paris: Fahrenheit, 2015. 


\section{BIBLIOGRAPHY}

Primary sources

Belfast Newsletter (Belfast).

Curtis, Edmund \& McDowell, R. B. (eds), Irish Historical Documents 1172-1922 (London, Methuen, 1968).

Freeman's Journal (Dublin).

Hansard, Parliamentary Debates, 3rd series.

Healy, Timothy, Letters and Leaders of My Day (London, T. Buttersworth, 1928).

Irish Times (Dublin).

Special Commission Act of 1888, Reprint of the Shorthand Notes of the Speeches, Proceedings, and Evidence Taken Before the Commissioners Appointed Under the Above-Named Act, 1890.

The Times (London).

Secondary sources

Bew, Paul, Charles Stewart Parnell (Dublin, Gill \& Macmillan, 1980).

Cawood, Ian, The Liberal Unionist Party, A History (London, I. B. Tauris, 2012).

Cecil, Lady Gwendolen, Life of Robert, Marquis of Salisbury (London, Hodder \& Soughton, 1931).

Girardet, Raoul, Mythes et mythologies politiques (Paris, Seuil, 1986).

Gray, Peter, "Ireland's last fetter struck off": the lord lieutenancy debate 1800-67", in

McDonough, Terry (ed.), Was Ireland a Colony? (Dublin, Irish Academic Press, 2005), pp. 87-101.

Hadfield, Andrew, Strangers to that Land: British Perceptions of Ireland from the Reformation to the Famine (Gerrards Cross, Colin Smythe, 1994).

Hammond, J. L., Gladstone and the Irish Nation (London, Frank Cass \& Co., 1964).

Hoppen, K. Theodore, “The Franchise and Electoral Politics in England and Ireland, 1832-1885", History 70 (January 1985), pp. 202-217.

Howard, Christopher H. D. (ed.), A Political Memoir by Joseph Chamberlain, 1880-92 (London, The Batchwork Press, 1953).

Howe, Stephen, Ireland and the Empire. Colonial legacies in Irish History and Culture (Oxford, Oxford University Press, 2000).

Jackson, Alvin, The Ulster Party, Irish Unionists in the House of Commons, 1884-1911 (Oxford, Clarendon Press, 1989).

Jackson, Alvin, Home Rule, An Irish History 1800-2000 (London, Weidenfeld \& Nicolson, 2003).

Lengel, Edward E., The Irish through British Eyes: Perceptions of Ireland in the Famine Era (Wesport, Praeger, 2002).

Lubenow, William C., Parliamentary Politics and the Home Rule Crisis (Oxford, Clarendon Press, 1988). 
O'Callaghan, Margaret, British High Politics and A Nationalist Ireland: Criminality, Land and the Law Under Forster and Balfour (Cork, Cork University Press, 1994).

O'Shea, Katharine, Charles Stewart Parnell: His Love Story and Political Life (New York, George H. Doran Company, 1914).

Perry Curtis Jr., Lewis, Apes and Angels, the Irishman in Victorian Caricature (Washington, Smithsonian Institution Press, 1997).

Shannon, Richard, Gladstone: Heroic Minister, 1865-1898 (London, Penguin, 1999).

Schnapper, Dominique, La Communauté des citoyens, Sur l'idée moderne de nation (Paris, Gallimard, 1994).

Schnapper, Dominique, Qu'est que la citoyenneté (Paris, Folio, 2000).

Walker, Brian M., “The Irish electorate 1868-1915”, Irish Historical Studies XVIII (1973), pp. 359-406.

Walker, Brian M., Parliamentary Results in Ireland, 1801-1922 (Dublin, Royal Irish Academy, 1978).

Yack, B., "The myth of the civic nation" in Beiner, Ronald (ed.), Theorising Nationalism (Albany, State University of New York, 1999), pp. 103-118.

\section{NOTES}

1. 'In all the independence movements in Europe and America in the 18th and 19th centuries, and in Asia and Africa in the 20th century, the claim for home rule was not distinct from the assertion of citizenship. It was in the name of citizenship that the colonised rebelled against the domination of

European colonisers.' D. Schnapper, Qu'est que la citoyenneté (Paris, Folio, 2000), p. 231.

2. S. Howe, Ireland and the Empire. Colonial legacies in Irish History and Culture, (Oxford, Oxford University Press, 2000).

3. P. Gray, "Ireland's last fetter struck off": the lord lieutenancy debate 1800-67", in Terry McDonough (ed.), Was Ireland a Colony? (Dublin, Irish Academic Press, 2005) pp. 87-101.

4. K. T. Hoppen, "The franchise and electoral politics in England and Ireland, 1832-1885", History 70 (January 1985), p. 215. See also B. M. Walker, “The Irish electorate 1868-1915”, Irish Historical Studies XVIII (1973), pp. 400-4.

5. Brian M. Walker, Parliamentary Results in Ireland, 1801-1922 (Dublin, Royal Irish Academy, 1978), p. XIII.

6. Lady G. Cecil, Life of Robert, Marquis of Salisbury (London, 1931), vol. III, pp. 125-64, notably p. 154.

7. Some historians have compared Gladstone's change of heart on the issue of Irish Home Rule as a "conversion". This is a contested version of the evolution of the Liberal's leader attitude towards the Irish question. R. Shannon writes notably that "Gladstone's becoming a Home Ruler commenced in November 1884 when Chamberlain having been encouraged by Gladstone since 1882 to keep fences mended with Parnell, concluded that the time was ripe for a big initiative of Irish local Government." However he does acknowledge what he calls an "epiphanal moment", "a precise moment (...) when Gladstone realized that he was a Home Ruler" which, according to him, took place "early in March." (R. Shannon, Gladstone: Heroic Minister, 1865-1898 (London, Penguin, 1999), pp. 352 \& 357-8).

8. Gladstone used former Liberal whip Lord Richard Grosvenor as his intermediary while Charles Stewart Parnell used his mistress Katherine O'Shea. During these exchanges Parnell submitted to 
Gladstone a "Draft Constitution for Ireland" (K. O'Shea, Charles Stewart Parnell: His Love Story and Political Life (New York, George H. Doran Compary, 1914), vol. II, p. 23-6 \& J. L. Hammond, Gladstone and the Irish Nation (London, Frank Cass \& Co, 1964), pp. 421-5).

9. Hansard, Parl. Deb., 3rd series, vol. 302, cols. 58-69.

10. Ibid., cols. 525-530

11. Ibid., cols. 533-4 \& 541-2.

12. Ibid., vol. 304, cols. 1036-85.

13. C.H.D. Howard (ed.), A Political Memoir by Joseph Chamberlain, 1880-92 (London, The Batchwork Press, 1953), pp. 194-8.

14. Ibid., pp. 224-5. Chamberlain indicates that two votes took place. During the first vote (done by show of hands), 35 Liberal Unionists agreed to vote against the Bill and 13 decided in favour of abstention. During the second vote - a more official ballot -45 Liberal Unionists chose to vote against the Bill. According to C. H. D. Howard, 39 and then 45 people actually opted for voting against the Bill (Ibid., p. 225, notes 1 et 2).

15. W. C. Lubenow, Parliamentary Politics and the Home Rule Crisis (Oxford, Clarendon Press, 1988), p. 338.

16. Hansard, Parl. Deb., 3rd series, vol. 304, col. 1039 (8 April 1886).

17. Ibid., cols. 1044-5.

18. Ibid., col. 1083.

19. Ibid., cols. 1275-7 (9 April 1886).

20. Hansard, Parl. Deb, 3rd series, vol. 306, cols. 58 \& 67 (25 May 1886).

21. Ibid., vol. 304, col. 1520 (13 April 1886).

22. Ibid., vol. 305, cols. 621-2 (10 May 1886).

23. Hansard, Parl. Deb., 3rd series, vol. 305, col. 644 (E. Ashmead-Bartlett, 10 May 1886).

24. Ibid., cols. 987-8 \& 994 (Lord G. F. Hamilton, 13 May 1886).

25. Ibid., vol. 306, cols. 1163-4 (G. Goschen, 7 June 1886).

26. Hansard, Parl. Deb., 3rd series, vol.305, cols. 369 \& 372 (28 May 1886).

27. A. Hadfield, Strangers to that Land: British Perceptions of Ireland from the Reformation to the Famine (Gerrards Cross, Colin Smythe, 1994), p. 148. See also Edward E. Lengel, The Irish through British Eyes: Perceptions of Ireland in the Famine Era (Wesport, Praeger, 2002).

28. L. Perry Curtis Jr., Apes and Angels, the Irishman in Victorian Caricature (Washington, Smithsonian Institution Press, 1997), p. 146.

29. The Times, 20 August 1887.

30. Ibid., 7, 10 et 14 March 1887; 18, 19, 20 \& 21 April $1887 ; 2,9,13$ \& 20 May 1887 et 1er, 7, 13, 23 \& 30 June 1887 .

31. The first letter dated from 15 May 1882, was published on 18 April 1888. A second letter, dated from 9 January 1882 and addressed to the President of the National Executive Committee of the Irish National League of America Patrick Egan, was published in July 1888. Both texts can be read in P. Bew, Charles Stewart Parnell (Dublin, Gill \& Macmillan, 1980), pp. 100 \& 105.

32. Parl. Deb., 3rd series, vol. 328, col. 1495 (17 July 1887). The Special Commission worked between September 1888 and November 1889 and published a report in February 1890. (Special Commission Act of 1888, Reprint of the Shorthand Notes of the Speeches, Proceedings, and Evidence Taken Before the Commissioners Appointed Under the Above-Named Act, 1890). Charles Stewart Parnell was heard by the Commission between 30 April and 8 May 1888 .

33. In February 1889, the Special Commission indicated that the letters had been forged by a man called Richard Pigott. (Freeman's Journal, 23 \& 27 February 1889)

34. M. O'Callaghan, British High Politics and a Nationalist Ireland: Criminality, Land and the Law Under Forster and Balfour (Cork, Cork University Press, 1994), pp. 114 \& 118. Callaghan seems to suggest that the Conservatives were successful in undermining Parnell's efforts and achievements (Ibid., p. 113) - an analysis shared by her colleague Alvin Jackson: "while Parnell 
was triumphantly vindicated, links between other ostensible constitutionalists and criminality had been firmly established, and a wider relationship between the Home Rule movement and militancy had been posited. The constitutionalist revision of Parnell's approach, which Gladstone so welcomed, had therefore been decisively checked" (A. Jackson, Home Rule, An Irish History 1800-2000 (London, Wiedenfeld \& Nicolson, 2003), p. 74).

35. Freeman's Journal, 18 octobre 1882.

36. T. Healy, Letters and Leaders of My Day (London, 1928), vol. I, p. 205 \& E. Curtis \& R. B. McDowell (eds), Irish Historical Documents 1172-1922 (London, Methuen, 1968), p. 281.

37. W.C. Lubenow, Parliamentary Politics and the Home Rule Crisis (Oxford, Clarendon Press, 1988) pp. $49-50 \& 160$.

38. Irish Times, 22 January 1886. As early as December 1885, Edward Saunderson, the new Conservative MP for North Armagh, had contemplated creating a distinct group of loyalist MPs in the Commons. This new party was officially launched at the Carlton Club on 24 January. From 1885 to 1918, this group of Irish unionists never had more than 23 MPs, but never fewer than 19.Despite being small it had a couple of secretaries who also acted as whips as well as a chairman (first Edward Saunderson until his death in 1906, then Walter Long from November 1906 to January 1910, and finally Edward Carson). However this party was never a fourth force in the British Parliament: “the pose of a separate 'Fourth Party' was a sham, for the Ulster group could exist only within the broad confines of Conservatism." (A. Jackson, The Ulster Party, Irish Unionists in the House of Commons, 1884-1911 (Oxford, Clarendon Press, 1989), pp. 44-46 \& 52)

39. Irish Times, 26 October \& 10 August 1885.

40. Belfast Newsletter, 9 January \& 1 May 1886.

41. I. Cawood, The Liberal Unionist Party, A History (London, I. B. Tauris, 2012), p. 145.

42. Hansard, Parl. Deb., 3rd series, vol. 305, col. 1348 (18 May 1886).

43. Hansard, Parl. Deb., 3rd series, vol. 306, cols. 115-6 (25 May 1886)

44. Ibid., vol. 306, col. 1172 (7 June 1886).

45. Ibid., vol. 305, col. 997 (13 May 1886)

46. Ibid., col. 631 (10 May 1886).

47. R. Girardet, Mythes et mythologies politiques (Paris, Seuil, 1986), pp. 153-4 \& B. Yack, "The myth of the civic nation" in R. Beiner (ed.), Theorising Nationalism (Albany, State University of New York, 1999), pp. 107 \& 115.

48. 'The modern nation has a specificity - it combines all populations into one community of citizens (...). A nation is defined by the ambition to use citizenship in order to transcend particular affiliations, whether they are biological (...), historical, economic, social, religious or cultural.' D. Schnapper, La Communauté des citoyens, Sur l'idée moderne de nation (Paris, Gallimard, 1994), p. 49.

49. Ibid., p. 50.

\section{ABSTRACTS}

This paper examines the relationship between nationality and citizenship in contexts of political and colonial domination. This relationship is explored through the study of the 1886 House of Commons debates on Irish Home Rule and the analysis of some of the speeches delivered by British and Irish MPs. 
Cet article cherche à examiner la relation existant entre nationalité et citoyenneté dans des contextes de domination politique et coloniale. Cette relation est ici étudiée à travers un exemple spécifique: celui des débats parlementaires de 1886 concernant l'autonomie législative de l'Irlande ou Home Rule, au cours desquels députes britanniques et irlandais associèrent diversement les deux notions.

INDEX

Mots-clés: nationalisme irlandais, home rule irlandais, unionisme, parti parlementaire irlandais Keywords: Irish nationalism, Irish Home Rule, unionism, Irish Parliamentary Party

\section{AUTHOR}

\section{PAULINE COLLOMBIER-LAKEMAN}

Université de Strasbourg 